\title{
ANALISIS PENGARUH FAKTOR INTERNAL BANK TERHADAP NON PERFORMING LOAN BERDASARKAN GENERALIZED METHOD OF MOMENT
}

\author{
Muhammad Samsul Maryandi \\ Magister Manajemen Universitas Muhammadiyah Yogyakarta \\ Jl. Lingkar Selatan, Tamantirto, Kasihan, \\ Bantul, Yogyakarta 55183 \\ Rizal Yaya dan Edi Supriyono \\ Fakultas Ekonomi Universitas Muhammadiyah Yogyakarta \\ Jl. Lingkar Selatan, Tamantirto, Kasihan, \\ Bantul, Yogyakarta 55183
}

\begin{abstract}
This research aims at finding out the effect of bank internal factors towards Non-Performing Loan (NPL). The internal factors of bank used in this study are credit expansion level, operational efficiency level, credit interest level, and the percentage of credit with problems in the previous period as dynamic effect. The research is very importantdue to thecondition that the ratio of NPL owned by the bank group tend to increase.Compared to previous studies (especially thosewhich took the case in Indonesia), this study had some strengths in terms of bigger sample size(using quarterly data of 97 banks during 2013 until 2015)and the use of Generalized Method of Moment(GMM) modelto analyze the effect of bank internal factor towards NPL. Based on theGMM model analysis, it can be concluded that the level of credit expansion, operational efficiency, credit interest and the percentage of credit with problems in aquarterly period ahead would give positive effect towards NPL in the following quarterly period. Meanwhile, the percentage of credit with problems in two quarterly periodsahead would give negative effect towards NPL in the followingquarterly period.
\end{abstract}

Keywords: NPL, bank internal factor, generalized method of moment

\section{PENDAHULUAN}

Sebagai lembaga intermediasi, bank sering dihadapkan dengan masalah risiko kredit. Risko ini diakibatkan oleh tidak mampunya debitur melunasi sebagian atau seluruh cicilan pinjaman yang diberikan bankataudisebutdenganterjadinya Non-

Korespondensi dengan Penulis:

Rizal Yaya HP +6289636751005

e-mail: yaya@umy.ac.id 
Performing Loan (NPL). Bholat, et al. (2016) mendefinisikan NPL terjadiketikajumlah yang diharapkan dibayar kembali lebih rendah dari nilai kontrak yang dinyatakan dalam neraca bank. Berdasarkan data Statistik Perbankan Indonesia per Juni 2008-2015, perkembangan rasio NPL Bank Umum Konvensional di Indonesia mengalami peningkatan, terutama pada beberapa periode terakhir.

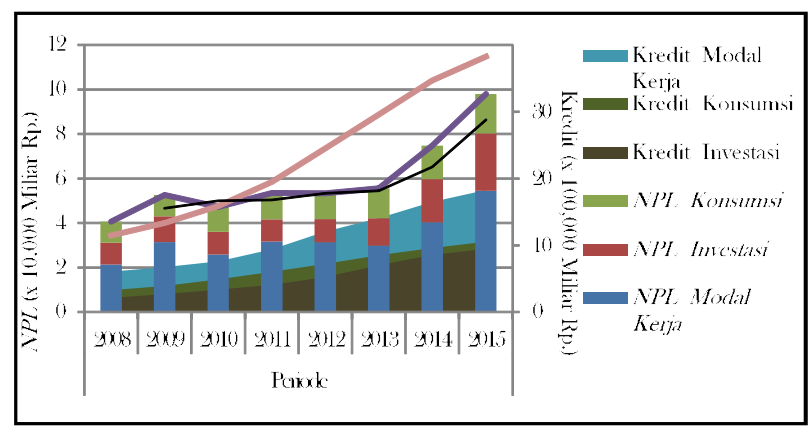

Gambar 1. Perkembangan Kredit dan NPL Bank Umum Konvensional di Indonesia Periode 2008-2015 Sumber: Bank Indonesia, 2008-2015 (diolah)

Rasio kredit bermasalahyang tinggi dapat berdampak kurang baik bagi kondisi finansial dan nonfinansial bank. Rendahnya kualitas debitur maupun perubahan perekonomian yang cepat dan sulit diprediksi dapat menjadi faktor yang sering memicu tingginya kredit bermasalah. Namun, didalam beberapa penelitian ditemukan juga bahwa faktor internal bank juga dapat memberikan dampak signifikan terhadap kualitas kredit, seperti pengaruh kualitas manajemen yang buruk, moral hazard, skimping, faktor kepemilikan, tingkat risiko kebangkrutan, diversifikasi dan kebijakan ekspansi kredit yang agresif (Louzis, et al. 2011). Bahkan pembebanan tingkat suku bunga kredit yang merupakan kompensasi risiko dapat menjadi penyebab terjadinya kredit bermasalah (Beck, et al. 2013; Abid, et al. 2014; Viswanadham \& Nahid, 2015).Oleh karena itu perlu dilakukan pengontrolan kredit, baik secara preventif maupun repressive. Pengendalian kualitas kredit sangat penting dilakukan untuk mengurangi terjadinya kredit dengan kualitas rendah.

Berdasarkan fakta diatas, perlu adanya bukti empiris terhadap faktor penyebab kredit bermasalah terutama dari sisi internal bank seperti tingkat ekspansi kredit, effisiensi sebagai indikator kualitas manajemen, suku bunga kredit, dan efek dinamik rasio NPLperiode sebelumnya. ${ }^{1}$

Untuk mentukan besarnya tingkat ekspansi kredit digunakan data Loan to Deposit Ratio, dengan asumsi jika rasio $L D R$ meningkat mengindikasikan bank sangat agresif dalam melakukan ekspansi kredit. Semakin besar ekspansi yang dilakukan, maka besar kemungkinan tingkat Non Performing Loan yang dimiliki akan meningkat dikemudian hari, akibat tidak selektif dalam memilih calon debitur dan kurangnya pengontrolan kredit (Louzis, et al. 2011).

Kemudian untuk mengukur tingkat effisiensi operasional, penelitian ini menggunakan data rasio BOPO (Beban Operasional atas Pendapatan Operasional). Dimana jika rasio BOPO meningkat maka tingkat effisiensi operasional yang dimiliki akan semakin rendah atau mengindikasikan kualitas manajemennya rendah. Rendahnya kualitas manajemen akan berdampak positif terhadap besarnya tingkat Non Performing Loan (Louzis, et al. 2011).

Sementara itu, untuk mengukur suku bunga kredit, penulis menggunakan tingkat suku bunga dasar kredit rata-rata pada setiap bank yang dijadikan sampel. Dimana jika tingkat kompensasi 


\section{Jurnal Keuangan dan Perbankan | PERBANKAN}

Vol. 20, No.3, September 2016: 496-506

risiko kredit yang dibebankan kepada debitur tinggi, maka akan berpotensi meningkatkan beban bunga debitur, sehingga dapat berpengaruh terhadap kualitas pembayaran pada periode berikutnya. Beck, et al. (2013),Abid, et al. (2014), Viswanadham dan Nahid (2015), Abebrese, et al. (2016) danKurti (2016) menyimpulkan bahwa tingkat suku bunga pinjaman memiliki pengaruh positif terhadap Non Performing Loan.

Sedangkan yang dimaksud efek dinamik rasio NPL periode sebelumnya yaitu efek NPL masa lalu (lag dari variabel dependen atau NPLt-n) sebagai faktor yang dapat mempengaruhi Non Performing Loan periode berikutnya. Louzis, et al. (2011) dalam penelitiannya menemukan bukti bahwa tingkat Non Performing Loan periode sebelumnya berpengaruh negatif terhadap Non Performing Loan periode berikutnya, akibat adanya pemutihan kredit.

\section{HIPOTESIS}

\section{Ekspansi Kredit}

Louzis, et al. (2011) dan Abid, et al.(2014) dalam penelitiannya menemukan adanya pengaruh positif tingka tekspansi kredit terhadap rasio NPL. Temuan tersebut menarik untuk dikaji mengingat penyaluran kredit merupakan kegiatan operasional utama bank untuk mendapatkan penghasilan bunga. Sangat agresifnya bank dalam penyaluran kredit tidak jarang membuat bank sering mengesampingkan unsur kehati-hatian, terutama dalam menyeleksi calon debitur yang berkualitas.

$\mathrm{H}_{1}$ : Diduga ekspansi kredit berpengaruh positif terhadap NPL.

\section{Kualitas Manajemen yang Buruk.}

Kualitas manajemen memiliki kontribusi yang sangat besar terhadap penentu dan pendukung produktivitas dalam sebuah organisasi, disamping dua variabel kritis lainnya seperti modal maupun tenaga kerja (Heizer dan Render, 2011). Rendah- nya kualitas manajemen pada sebuah bank tentu dapat berdampak buruk bagi kegiatan operasionalnya, termasuk dalam pengelolaan portofolio kredit. Untuk mengukur besarnya kualitas manajemen, Louzis, et al. (2011) menggunakan indikator besarnya tingkat effisiensi yang diukur menggunakan rasio $B O P O$ (rasio beban operasional terhadap pendapatan operasional)

$\mathrm{H}_{2}$ : Diduga effisiensi operasional berpengaruh positif terhadap NPL.

\section{Tingkat Suku Bunga Kredit}

Suku bunga kredit merupakan sebuah kompensasi yang dibebankan bank kepada debitur terhadap risiko dalam kredit yang disalurkan. Namun dalam faktanya, pembebanan tingkat suku bunga kredit yang tinggi justru dapat memicu terjadinya kredit bermasalah. Pengaruh positif tingkat suku bunga kredit terhadap kredit bermasalah ditemukan pada beberapa penelitian terdahulu, seperti Beck, et al. (2013), Abid, et al. (2014), Viswanadham \& Nahid (2015), Abebrese, et al. (2016) danKurti (2016).

$\mathrm{H}_{3}$ : Diduga tingkat suku bunga berpengaruh positif terhadap NPL.

\section{Efek Dinamik NPL Periode Sebelumnya.}

Tingkat kredit bermasalah yang tinggi pada periode sebelumnya sering meningkatkan rasio NPL periode berikutnya. Tidak mempunya bank dalam mengatasi kredit bermasalah akan berdampak pada peningkatan beban cadangan penurunan dan kerugian kredit. Untuk menjaga cash rationya, bank akan melakukan hapus buku (write-off) piutang yang tergolong tidak lancar. Dana-danayang dihapus buku akan dicatat di rekening administratif bank.Upayahapus bukupada kredit bermasalah periode sebelumnya menurut Louzis, et al.(2011) dan Abid, et al. (2014) dapat berpengaruh negatif terhadap rasio NPL periode berikutnya. 


\section{Analisis Pengaruh Faktor Internal Bank terhadap Non Performing Loan Berdasarkan Generalized Method of Moment}

Muhammad Samsul Maryandi \& Rizal Yaya dan Edi Supriyono

$\mathrm{H}_{4}$ : Diduga efek dinamik NPL periode sebelumnya berpengaruh negatif terhadap NPL periode berikutnya.

\section{METODE}

\section{Sampel}

Sampel yang digunakan sebanyak 97 bank dari total 106 Bank Umum Konvensional yang beroperasi di Indonesia. Sembilan puluh tujuh sampel tersebut terdiri dari 4 Bank BUMN, 29 BUSN Devisa, 20 BUSN Non Devisa, 26 Bank Pembangunan Daerah, 11 Bank Campuran, dan 7 Bank Asing. Kriteria yang digunakan untuk memilih sampel yaitu: (1) mempublikasikan data yang dibutuhkan dalam penelitian, (2) memiliki rasio NPL diatas nol persen, dan (3) tidak melakukan merger atau konversi usaha selama periode analisis.

\section{Jenis dan Sumber Data}

Data yang digunakan berbentuk cross section dan time series, mulai dari kuartal II 2013 sampai kuartal II 2015 yang diperoleh dari Bank Indonesia dan Otoritas Jasa Keuangan. ${ }^{2}$

\section{Teknik Pengambilan Data}

Pengumpulan data penelitian dilakukan dengan pencatatan secara langsung terhadap data yang dibutuhkan dari situs Bank Indonesia ( $\underline{w w w}$. $\underline{\text { bi.go.id }})$ dan Otoritas Jasa Keuangan (www.ojk.go.id $)$.

Tabel 1. Definisi Operasional Penelitian

\begin{tabular}{|c|c|c|}
\hline Variabel & Konsep & Referensi \\
\hline NPL Gross & $\begin{array}{l}\text { Tingkat kredit yang tergolong default atau memiliki } \\
\text { kualitas yang rendah.Rumus: } \\
N P L=\frac{\text { Kredit bermasalah }}{\text { Kredit yang disalurkan }} \times 100 \%\end{array}$ & $\begin{array}{l}\text { Louzis, et al.(2011) } \\
\text { Abid, et al.(2014) } \\
\text { Ozili, et al.(2015) }\end{array}$ \\
\hline$L D R$ & $\begin{array}{l}\text { Besarnya tingkat ekspansi kredit yang dilakukan } \\
\text { bank.Rumus: } \\
L D R=\frac{\text { Kredit }}{\text { Dana Pihak Ketiga }} \times 100 \%\end{array}$ & Louzis, et al.(2011) \\
\hline BOPO & $\begin{array}{l}\text { Tingkat effisiensi yang dilakukan bank dalam kegiatan } \\
\text { operasionalnya.Rumus: } \\
\qquad B O P O=\frac{\text { Total beban operasional }}{\text { Total pendapatan operasional }} \times 100 \%\end{array}$ & $\begin{array}{l}\text { Louzis, et al.(2011) } \\
\text { Abid, et al.(2014) }\end{array}$ \\
\hline Tingkat SBDK & $\begin{array}{l}\text { Tingkat suku bunga dasar kredit rata-rata setiap bank } \\
\text { pada periode ke-n. Digunakan untuk mengukur tingkat } \\
\text { kompensasi yang dibebankan bank kepada debitur atas } \\
\text { risiko kredit. }\end{array}$ & $\begin{array}{l}\text { Beck, et al. (2013) } \\
\text { Viswanadham \& Nahib } \\
\text { (2015) }\end{array}$ \\
\hline $\begin{array}{l}\text { NPL Gross periode } \\
\text { sebelumnya }\end{array}$ & $\begin{array}{l}\text { Kredit yang tergolong default pada periode sebelumnya. } \\
\text { Variabel ini digunakan untuk mengukur pengaruh kredit } \\
\text { bermasalah masa lalu terhadap NPL periode berikutnya. }\end{array}$ & $\begin{array}{l}\text { Louzis, et al.(2011) } \\
\text { Abid, et al.(2014) } \\
\text { Ozili, et al.(2015) }\end{array}$ \\
\hline
\end{tabular}

Per 31 Desember 2013, seluruh informasi dan data yang berkaitan dengan perbankan beralih ke OJK. 


\section{Jurnal Keuangan dan Perbankan | PERBANKAN}

Vol. 20, No.3, September 2016: 496- 506

\section{Definisi Operasional}

Berikut tabel definisi operasional faktor internal bank yang digunakan dalam penelitian:

\section{Uji Kualitas Data}

Uji kualitas data yang digunakan dalam penelitian mencakup ujiunit root,kointegrasi, validitas instrumen, dan autokorelasi. Uji unit root digunakan untuk mendeteksi komponen trendrandom walk pada data runtun waktu. Pada uji ini digunakan pendekatan Breitung $t$-stat dan Im, Pesaran and Shin W-stat dengan hipotesis nol $\left(\mathrm{H}_{0}\right.$ : $\rho=0$ )yaitu terdapat akar unit dalam data. Menurut Rosadi (2012) uji unit root penting dilakukan sebagai persyaratan data yang berkointegrasi untuk mendeteksi arah trend yang sama antar variabel. Selain tidak menyebabkan bias analysis, penggunaan variabel yang berkointegrasi dapat digunakan untuk mendeteksi pengaruh jangka panjang (Rosadi, 2012). Pada uji kointegrasidigunakan pendekatan Pedroni Residual Cointegration Test dengan hipotesis nol $\left(\mathrm{H}_{0}: \alpha=0\right)$ yaitu tidak ditemukan adanya kointegrasi antar variabel.

Berbeda dengan uji unit root dan kointegrasi yang digunakan untuk menguji kualitas data pada analisis jangka panjang, uji validitas instrumen dan autokorelasisecara spesifik akan digunakan untuk menguji kualitas estimasi dalam persamaan. Uji validitas instrumen digunakan untuk mendeteksi kemungkinan adanya bias pada parameter estimasi akibat tidak tepatnya penggunaan variabel intsrumen dalam persamaan. Pada uji ini digunakan pendekatan Sargan Specification Testdengan hipotesis $\operatorname{nol}\left(\mathrm{H}_{0}: \mathrm{z}=0\right)$ yaitu ditemukan adanya conditions of moment yang valid dalam model. Sementara itu, uji autokorelasidigunakan untuk mendeteksi adanya autokorelasi orde kedua dari differensi error term yang menyebabkan korelasi serial pada error term ditingkat level (Louzis, et al. 2011). Pada uji ini digunakan pendekatan Arellano-Bond Serial Correlation Test dengan hipotesis nol $\left(\mathrm{H}_{0}: \Delta \mu_{\mathrm{i}, \mathrm{t}}=0\right)$ yaitu ditemukan adanya autokorelasidalam persamaan.

\section{Metode Analisis Data}

Penelitian ini menggunakan model analisis GMM. Model tersebut merupakan sebuah model panel dinamik, ditandai dengan adanya lagvariabel dependen diantara variabel independennya (Hsiao \& Yanan, 2006) dan merupakan penyempurnaan dari metode instrumental variabel (Arellano \& Bond, 1991). Berikut persamaan model GMM (Louzis, et al. 2011):

$\Delta \mathcal{Y}_{i, t}=\gamma \Delta \mathcal{Y}_{i, t-1}+\beta \Delta X_{i, t}+\Delta \mu_{i, t}$

Dimana: $y$ (variabel dependen $i) ; \gamma$ (konstanta); $\beta$ (koefisien); X (variabel independen); $i$ (cross section); $t$ (periode); $\varepsilon$ (error term).

Model ini dapat menghilangkan efek individu yang tidak terobservasi dan korelasi antara $y_{i,-1}$ dan $\mu_{i, t}$ karena dimasukkannya variabelinstrumen dalam model.

$$
\begin{aligned}
\Delta N P L_{i, t}= & \gamma \Delta N P L_{i, t-n}+\beta_{1} \Delta E K P_{i, t-n}+\beta_{2} \Delta E F F_{i, t-n}+ \\
& \beta_{3} \Delta R_{i, t-n}+\Delta \mu_{i, t} \quad \ldots \ldots \ldots \ldots \ldots \ldots \ldots \ldots \ldots \ldots \ldots \ldots \ldots \ldots \ldots \ldots \ldots \ldots \ldots \ldots
\end{aligned}
$$

Selain menguji pengaruh faktor internal bank dalam bentuk lag, akan dilakukan juga estimasi jangka panjang (long-run effects). Estimasi jangka panjang diperoleh dengan mengakumulasi koefisien setiap variabel penjelas yang didapat dari model GMM, dengan rumus (Louzis, et al. 2011):

$\beta_{n}^{x}=\sum_{i=1}^{n} \beta_{n j} /(1-\gamma)$

Sementara itu, untuk menghitung variance koefisien jangka panjang digunakan rumus (Stuart \& Ord, 1998 dalam Louzis, et al. 2011):

$\operatorname{Var}\left(\beta_{\mathrm{n}}^{\mathrm{X}}\right)=\frac{\left(\sum_{j=1}^{\mathrm{n}} \beta_{\mathrm{nj}}\right)^{2}}{(1-\gamma)^{2}}\left[\frac{\operatorname{Var}\left(\sum_{j=1}^{\mathrm{n}} \beta_{\mathrm{n}}\right)}{\left(\sum_{j=1}^{\mathrm{n}} \beta_{\mathrm{nj}}\right)^{2}}-2 \frac{\operatorname{Cov}\left(\left(\sum_{\mathrm{j}=1}^{\mathrm{n}} \beta_{\mathrm{nj}}\right),(1-\gamma)\right)}{\left(\sum_{\mathrm{j}=1}^{\mathrm{n}} \beta_{\mathrm{nj}}\right)(1-\gamma)}+\frac{\operatorname{Var}(\alpha)}{(1-\gamma)^{2}}\right] \ldots \ldots$

Dari persamaan (4) diperoleh Standard Error dengan rumus: 
$\operatorname{SE}\left(\beta_{n}^{x}\right)=\sqrt{\operatorname{Var}\left(\beta_{\mathrm{n}}^{\mathrm{x}}\right)}$

Dari persamaan (3) dan (5) diperoleh nilai tstatistik dengan rumus:

$\mathrm{t}^{*}=\beta_{n}^{x} / \mathrm{SE}\left(\beta_{n}^{x}\right)$

\section{HASIL}

\section{Uji Kualitas Data}

Berikut tabel yang menunjukkan hasil uji kualitas data, mencakup unit root test, uji kointegrasi, uji validitas instrumen dan uji autokorelasi.

Tabel 2. Hasil Uji Kualitas Data

\begin{tabular}{|c|c|c|c|c|c|}
\hline \multicolumn{3}{|c|}{ Unit Root } & \multicolumn{2}{|c|}{ Kointegrasi } & \multirow[t]{2}{*}{ Validitas instrumen } \\
\hline Variabel & Prob.Common & $\overline{\text { Prob.Individual }}$ & $\begin{array}{l}\text { Prob. Common } \\
\text { AR coefs. }\end{array}$ & $\begin{array}{c}\text { Prob.Individual } A R \\
\text { coefs. }\end{array}$ & \\
\hline NPL & 1,0000 & 0,8052 & 0,0004 & 0,0000 & Prob. (J-stat) \\
\hline$L D R$ & 0,1530 & 0,3395 & \multicolumn{2}{|c|}{ Autokorelasi } & 0,127435 \\
\hline BOPO & 0,9969 & 0,9140 & Prob. AR (1) & Prob.AR(2) & \\
\hline $\mathrm{R}$ & 1,0000 & 0,7143 & 0,0042 & 0,7823 & \\
\hline
\end{tabular}

Sumber: Data (diolah)

Tabel 3. Hasil Analisis GMM

\begin{tabular}{|c|c|c|c|c|c|}
\hline Variabel & Koef. & Stats. & Variabel & Koef. & Stats. \\
\hline \multicolumn{6}{|c|}{ Panel A: Individual lag coefficients estimation } \\
\hline NPL(-1) & 0,194120 & $3,268576^{* * *}$ & $\mathrm{R}$ & $-0,028347$ & $-0,75526$ \\
\hline NPL(-2) & $-0,166949$ & $-5,8318^{* * *}$ & $\mathrm{R}(-1)$ & 0,083213 & $3,67089^{* * *}$ \\
\hline$L D R$ & 0,002547 & $4,82823^{* * *}$ & $\mathrm{R}(-2)$ & 0,027513 & 0,82083 \\
\hline$L D R(-1)$ & 0,002871 & $2,38554^{* *}$ & $\mathrm{R}(-3)$ & 0,039553 & $1,96513^{* *}$ \\
\hline$L D R(-2)$ & 0,001047 & $2,62225^{* * *}$ & @LEV(@ISPERIOD("2014Q & 0,026883 & 0,41961 \\
\hline $\operatorname{LDR}(-3)$ & 0,005085 & $3,75620^{* * *}$ & @̈L̀EV(@ISPERIOD("2014Q & 0,020023 & 0,41028 \\
\hline ВОРО & 0,049865 & $7,69763^{* * *}$ & @̈LEV(@ISPERIOD("2014Q & $-0,109218$ & $-1,78149^{*}$ \\
\hline BOPO(-1) & $-0,003991$ & $-0,7334$ & @̈LEV(@ISPERIOD("2015Q & 0,155601 & $2,92713^{* * *}$ \\
\hline$B O P O(-2)$ & 0,007261 & $2,64264^{* * *}$ & @LEV(@ISPERIOD("2015Q & $-0,003503$ & $-0,05019^{*}$ \\
\hline$B O P O(-3)$ & 0,034407 & $7,72721^{* * *}$ & & & \\
\hline
\end{tabular}

Panel B: Long-run coefficients estimation

\begin{tabular}{lll} 
LDR & 0,010373 & $3,86006^{* * *}$ \\
BOPO & 0,091793 & $3,00544^{* *}$ \\
R & 0,116027 & $2,44387 * *$ \\
\hline
\end{tabular}

Effects Specification

\begin{tabular}{lllll}
\hline \multicolumn{4}{l}{ Cross-section fixed (first differences), Period fixed (dummy variables) } & \\
\hline Mean dependent var & 0,143072 & Prob(J-statistic) & 0,127435 & Sum squared resid 329,0003 \\
S,E, of regression & 0,840244 & S,D, dependent var & Instrument rank & 42 \\
J-statistic & 30,81386 & & &
\end{tabular}

Ket: signifikan pada tingkat kesalahan ${ }^{* * *} 1 \%,{ }^{* *} 5 \%,{ }^{*} 10 \%$

Sumber: Data (diolah) 


\section{Jurnal Keuangan dan Perbankan | PERBANKAN}

Vol. 20, No.3, September 2016: 496- 506

Dari tabel diatas dapat disimpulkan bahwa data yang digunakan memiliki akar unit, ber kointegrasi, memiliki variabel instrumen yang valid dan tidak ditemukan adanya autokorelasi orde kedua dari differensi error term yang berdampak pada korelasi serial error term ditingkat level.

\section{GMM dan Pengaruh jangka panjang}

Berikut tabel yang menunjukkan hasil analisis uji GMMdan pengaruh jangka panjang faktor internal bank terhadap NPL:

Hasil analisis GMMdiatas memperlihatkan bahwa tingkat ekpansi kredit, effisiensi operasional, suku bunga kredit dan efek dinamik kredit bermasalah satu periode sebelumnya berpengaruh positif terhadap NPL. Sementara itu, efek dinamik kredit bermasalah dua periode sebelumnya ditemukan berpengaruh negatif terhadap NPL.Dilihat dari nilai koefisiennya, efek dinamik kredit bermasalah satu periode sebelumnya memiliki pengaruh paling besar terhadap NPL.

Kemudian dalam analisis jangka panjang, disimpulkan bahwa tingkat ekspansi kredit, effisiensi operasional dan suku bunga kredit secara individu berpengaruh signifikan terhadap NPL. Dimana dari tiga variabel yang berpengaruh, tingkat suku bunga kredit memiliki nilai koefisien terbesar. Artinya dibandingkan dengan dua variabel lainnya, tingkat suku bunga kredit memiliki pengaruh paling besar terhadap NPLdalam jangka panjang.

\section{PEMBAHASAN}

\section{Ekspansi Kredit}

Ditemukannya pengaruh positif tingkat ekspansi kredit terhadap NPLsejalan dengan hasil penelitian yang dilakukan oleh Louzis, et al.(2011), Abid, et al. (2014)danAbebrese, et al. (2016). Tidak diterapkannya prinsip kehati-hatian dalam memilih calon debitur yang berkualitas saat akan menyalur- kan kredit oleh bank merupakan faktor penyebab utama terjadinya hubungan positif tersebut. Prinsip kehati-hatian dalam menyalurkan kredit mutlak harus dilakukan oleh bank sebagai langkah preventive untuk mengendalikan kualitas kredit. Dilihat dari nilai koefisien yang dimiliki, dapat disimpulkan bahwa perubahan rasio NPL sangat sensitive terhadap ekpansi kredit tiga kuartal sebelumnya. Selain itu, pengaruh ekspansi kredit terhadap NPLjuga berdampak dalam jangka panjang.

Untuk menekan terjadinya kerugian kredit yang lebih besar pihak bank harus benar-benar mengontrol proses penyaluran kredit dengan baik dan benar sejak dini. Terdapat tiga metode yang dapat dilakukan bank dalam pengendalian kualitas kredit (Malayu \& Hasibuan, 2005), yaitu menyesuaikan plafon kredit dengan profil risiko debitur, monitoring, dan pembinaan debitur. Selain tiga metode tersebut, bank juga harus menilai agunan dengan tepat karena dapat menjadi sumber likuiditas ketika debitur mengalami gagal bayar. Selain itu, agunan dapat juga dijadikan sebagai pengikat tanggung jawab debitur atas kewajibannya. Lemahnya nilai agunan dapat menjadi faktor keengganan debitur memenuhi kewajibannya (Waweru \& Kalani, 2009;Mirza \& Majumder, 2014).

\section{Tingkat Effisiensi Operasional}

Ditemukannyapengaruh positif tingkat effisiensi operasional terhadap NPL sejalan dengan hasil penelitian yang dilakukan oleh Louzis, et al.(2011)danAbebrese, et al. (2016). Hubungan tersebut mengindikasikan bahwa jika bank memiliki kualitas manajemen yang rendah, maka besar kemungkinan tingkat kredit bermasalah yang dimiliki akan meningkat. Sebaliknya, jika kualitas manajemen yang dimiliki bank baik, maka tingkat kredit bermasalah yang dimiliki bank akan rendah. Mengacu dari besar nilai koefisien yang dimiliki, perubahan rasio kredit bermasalah Bank Umum Konvensional di Indonesia sangat sensitif terhadap pergerakan tingkat effisiensi operasional yang 
dimiliki pada periode yang sama. Selain itu, pengaruh tingkat effisiensi operasional terhadap NPLjuga berdampak dalam jangka panjang.

Dalam dunia perbankan, kualitas manajemen yang buruk dapat dilihat dari tidak optimalnya pihak bank dalam memonitor dan mengontrol biaya operasionalnya, yang dapat direfleksikan dari efisiensi biaya yang rendah. Selain itu, tidak diterapkannya beberapa kesepakatan yang cukup dalam pinjaman juga menjadi tanda rendahnya tingkat kualitas manajemen. Hal ini dapat dilihat dari rendahnya kemampuan bank dalam pengskoran kredit dan rendahnya kompetensi dalam menilai kualitas agunan. Bahkan ketika kredit telah disalurkan, pihak bank kesulitan dalam memonitoring debiturnya. Buruknya kualitas manajemen seperti yang diindikasikan dengan beberapa indikator diatas dapat berdampak kurang baik terhadap kualitas aset yang dimiliki bank. Kualitas manajemen yang buruk menjadi faktor utama penyebab tingginya rasio NPL (Louzis, et al. 2011).Oleh karena itu, untuk menekan kredit bermasalah, bank harus meningkatkan kualitas manajemen, mulai dari analis kredit sampai dengan pembuat kebijakan perkreditan.

\section{Tingkat Suku Bunga Kredit}

Ditemukannya pengaruh positif tingkat suku bunga kredit terhadap NPL sejalan dengan penelitian Beck, et al. (2013), Abid, et al. (2014), Vismawanadham \&Nahid (2015),Abebrese, et al. (2016) danKurti (2016).Mengacu dari tingkat sensitivitas yang dimiliki, mengindikasikan bahwa pihak debitur benar-benar sangat sensitif untuk mengalami gagal bayar ketika terjadi kenaikan tingkat suku bunga kredit. Sebaliknya jika tingkat suku bunga kredit rendah, maka tingkat kredit bermasalah akan rendah akibat rendahnya beban bunga yang ditanggung oleh debitur. Adanya pengaruh positif dalam jangka pendek dan panjang tentu menunjukkan tandayang kurang baik bagi sebuah bank, mengingat tingkat suku bunga kredit merupakan sebuah kompensasi risiko bagi pihak perbankan. Artinya jika risiko default debitur tinggi, maka besar kemungkinan bank akan menetapkan tingkat suku bunga kredit yang tinggi pula.

Terjadinya peningkatan tingkat suku bunga kredit tentu berpotensi meningkatkan beban bunga bagi debitur. Untuk mengatasi hal tersebut, diperlukan adanya penyesuaian yang akurat pada profil risiko debitur dengan tingkat suku bunga kredit yang akan dibebankan, disamping menyesuaikan kuantitas kredit dan persyaratan nilai agunan sebagai jaminan atas adanya risiko default. Penyesuaian profil risiko debitur dengan pembebanan tingkat suku bunga kredit dapat dilakukan dengan memperhatikan beberapa aspek biaya pada komponen pembentuk tingkat suku bunga kredit, seperti premi resiko, margin dan biaya administrasi.

\section{NPLPeriode Sebelumnya}

Ditemukannyapengaruh positif NPL satu kuartal sebelumnya terhadap perubahan rasio NPL sejalan dengan hasil penelitian yang dilakukan oleh Beck, et al. (2013). Menurut Beck, et al. (2013), dampak ketidak beruntungan bank akibat tidak tertanganinya kredit bermasalah pada periode sebelumnya menjadi penyebab terjadinya peningkatan rasio NPL pada periode berikutnya.

Sementara itu, ditemukannya pengaruh negatif NPL dua kuartal sebelumnya terhadap NPL sejalan dengan penelitian yang dilakukan Louzis, et al. (2011) dan Abid, et al. (2014). Untuk menjaga agar cash ratio tidak terganggu, bank akan melakukan hapus buku (write-off) piutang yang tergolong tidak lancar. Dana-dana yang dihapus buku tersebut akan dicatat di rekening administratif bank. Dalam praktiknya, hapus buku dapat dilakukan dengan dua metode, yaitu bersyarat dan mutlak. Hapus buku bersyarat memiliki kelebihan dibandingkan hapus buku secara mutlak, yaitu 


\section{Jurnal Keuangan dan Perbankan | PERBANKAN}

Vol. 20, No.3, September 2016: 496- 506

masih adanya hak tagih bank. ${ }^{3}$ Untuk mengembalikan kredit bermasalah tersebut, bank dapat melakukannya dengan rescheduling, reconditioning, restrukturisasi, dan melikuidasiagunan debitur. Sebaliknya untuk hapus buku secara mutlak, pihak bank sudah tidak memiliki hak tagih dan sudah dianggap rugi. Dilihat dari tingkat preferensinya, dari 97 sampel hanya 29 persen bank yang melakukan hapus tagih. Sementara itu, 87 persen dari sampel melakukan hapus buku bersyarat setiap periodenya.

\section{KESIMPULAN}

Berdasarkan hasil analisis GMMdiatas, dapat disimpulkan bahwa tingkat ekspansi kredit yang diukur menggunakan Loan to Deposit Ratio memiliki pengaruh positif terhadap NPL. Temuan tersebut sejalan dengan penelitian yang dilakukan oleh Louzis,et al. (2011) dan Abid,et al. (2014). Ditemukannya pengaruh positif mengindikasikan bahwa ekspansi kredit yang dilakukan bank belum diimbangi dengan pengendalian kualitas kredit secara optimal, terutama dalam memilih calon debitur berkualitas. Rendahnya upaya pengendalian kualitas kredit dapat dilihat dari meningkatnya rasio NPL dalam beberapa periode terakhir.

Variabel tingkat effisiensi operasional yang diukur menggunakan rasio BOPO disimpulkan berpengaruh positif terhadap NPL. Temuan tersebut sejalan dengan penelitian yang dilakukan oleh Louzis, et al.(2011)danAbebrese, et al. (2016). Untuk menekan kredit bermasalah, perlu dilakukan peningkatan kualitas manajemen, terutama pada unit yang berkaitan langsung dengan proses perkreditan.

Variabel tingkat suku bunga kredit dalam analisis disimpulkan memiliki pengaruh positif terhadap NPL. Temuan tersebut sejalan dengan hasil penelitian yang dilakukan oleh Beck,et al. (2013),
Abid, et al. (2014), Vismawanadham \& Nahid (2015), Abebrese, et al. (2016) danKurti (2016). Ditemukannya pengaruh positif mengindikasikan tanda yang kurang baik bagi bank, karena merupakan sebuah kompensasi atas risiko default debitur. Oleh karena itu, perlu dilakukan penyesuaian profil risiko debitur dengan tingkat suku bunga kredit, disamping menyesuaikan kuantitas kredit dan persyaratan agunan. Penyesuaian profil risiko debitur dengan tingkat suku bunga kredit dapat dilakukan dengan memperhatikan aspek biaya pembentuk suku bunga kredit, seperti premi resiko, margin dan biaya administrasi.

NPL satu periode sebelumnya ditemukan berpengaruh positif terhadap NPL, sedangkan NPL dua periode sebelumnya ditemukan berpengaruh negatif. Ditemukannya pengaruh positif NPL satu periode sebelumnya sejalan dengan penelitian yang dilakukan oleh Beck, et al. (2013). Sementara itu, pengaruh negatif NPL dua periode sebelumnya sejalan dengan hasil penelitian yang dilakukan oleh Louzis,et al. (2011) dan Abid,et al. (2014). Dimana hubungan negatif tersebut menurut Louzis,et al. (2011) diakibatkan oleh adanya program hapus buku (write-off).

\section{SARAN}

Bagi Bank Umum Konvensional agar selalu meningkatkan kualitas kreditnya, baik melalui metode preventive maupun repressive. Metode preventive dapat dilakukan dengan menilai calon debitur dengan baik, penetapan plafon kredit dan suku bunga kredit secara tepat, pembinaan dan pengontrolan debtur. Sementara itu, metode repressive dapat dilakukan dengan rescheduling, reconditioning, restructuring, dan likuidation. Selain itu diperlukan program hapus buku pada kredit macet sehinggacash ratio dan kebijakan perkreditan bank tetap terjaga. 


\section{Analisis Pengaruh Faktor Internal Bank terhadap Non Performing Loan Berdasarkan Generalized Method of Moment}

Muhammad Samsul Maryandi \& Rizal Yaya dan Edi Supriyono

Sementara ituuntuk penelitian selanjutnya, penulis menyarankan agar memasukkan faktor internal bank yang tidak digunakan dalam penelitian, seperti diversifikasi, tingkat kepemilikan, permodalan, total aset, dan beberapa faktor internal lain yang diduga dapat berpengaruh terhadap NPL.

\section{DAFTAR PUSTAKA}

Abebrese, G. O., Pickson, R.B. \&Opare, E. 2016. The Effect of Bank Specific Factors on Loan Performance of HFC Bank in Ghana, International Journal of Economics and Finance, 8 (7): 185-192.

Abid, L., Ouertani, M.N., \& Ghorbel, S.Z. 2014. Macroeconomic and Bank-spesific Determinants of Household's Non-performing Loans in Tunisia: a Dynamic Panel Data, Procedia Economics and Finance, 13: 58-68.

Arellano, M., \& Bond, S. 1991. Some Tests of Specification for Panel Data: Monte Carlo Evidence and An Application to Employment Equations, Oxford Journals, 58 (2): 277-297.

Bank Indonesia. 2008. Statistik Perbankan Indonesia, Jakarta: BI. Jakarta: BI.

2009. Statistik Perbankan Indonesia,

2010. Statistik Perbankan Indonesia Jakarta: BI.

2011. Statistik Perbankan Indonesia, Jakarta: BI.

2012. Statistik Perbankan Indonesia, Jakarta: BI.

Jakarta: BI.

2013. Statistik Perbankan Indonesia,

2014. Statistik Perbankan Indonesia, Jakarta: BI.

2015. Statistik Perbankan Indonesia, Jakarta: BI.

Beck, R., Jakubik, P., \& Piloiu, A. 2013. Non-performing Loans: What Matters in Addition to The Economic Cycle?, Macroprudential Research Network, (pp. 1-
32). Frankfurt, Germany: European Central Bank.

Bholat, D., Lastra, R., Markose,S., Miglionico, A, \&Sen, K. 2016.Non-performing loans: regulatory and accounting treatments of assets, Staff Working Paper No. 594, Bank of England.

Down, K. 1998. Beyond Value at Risk: The New Science of Risk Management. John Wiley \& Sons: New York.

Hsiao, C., \& Yanan, W. 2006. Panel Data Analysis: Advantages and Challenges. Xiamen University.

Kurti, L. 2016. Determinants of Non-Performing Loans in Albania, TheMacrotheme Review, 5(1): 60-72.

Louzis, D.P., Vouldis, A.T., \& Metaxas, V.L. 2011. Macroeconomic and Bank-spesific Determinants of Nonperforming Loans in Greece: A Comparative Study of Mortage, Business and Consumer Loan Portofolios, Journal of Banking E Finance, 1-16.

Malayu \& Hasibuan. 2005. Dasar-Dasar Perbankan. Edisi 4. Jakarta: Bumi Aksara.

Mirza, A.B.\& Majumder, D. 2014. Non-performing Loan in Banking Sector of Bangladesh: Causes and Effect.BRAC University.

Otoritas Jasa Keuangan. 2013. Statistik Perbankan Indonesia, Jakarta: OJK.

2014. Statistik Perbankan Indonesia, Jakarta: OJK.

sia, Jakarta: OJK.

Ozili, P.K. 2015. How Bank Managers Anticipate Nonperforming Loans: Evidence from Europe, US, Asia and Africa, Applied Finance and Accounting, 4(2): 112.

Rosadi, D. 2012. Ekonometrika dan Analisis Runtun Waktu Terapan dengan EViews: Aplikasi untuk Bidang Ekonomi, Bisnis dan Keuangan. Edisi 1. Yogyakarta: C.V. Andi Offset.

Saba, I., Rehana, K., \& Azeem, M. 2012. Determinants of Non Performing Loans: Case of US Banking Sector, The Romanian Economic Journal,44(6): 125-136.

Sounders, A., \& Cornet, M.M. 2011. Financial Institutions Management: A Risk Management Approach. Seventh Edition. NY: McGraw-Hill Companies Inc. 


\section{Jurnal Keuangan dan Perbankan | PERBANKAN}

Vol. 20, No.3, September 2016: 496- 506

Viswanadham, N. \& Nahid. 2015. Determinants of Non Performing Loans in Commercial Banks: A Study of NBC Bank Dodoma Tanzania, International Journal of Finance \& Banking Studies, 4(1): 70-94.
Waweru, N.M., \& Kalani, V.M. 2009. Commercial Banking Crises in Kenya: Cause and Remedies, Global Journal of Finance and Banking Issues, 3(3): 23-43. 